\title{
Protection from Near-Infrared to Prevent Skin Damage*
}

\author{
Yohei Tanaka, Lisa Gale \\ Clinica Tanaka Plastic, Reconstructive Surgery and Anti-Aging Center, Matsumoto, Nagano, Japan \\ Email: info@clinicatanaka.jp
}

Received 24 February 2015; accepted 28 March 2015; published 31 March 2015

Copyright (C) 2015 by authors and Scientific Research Publishing Inc.

This work is licensed under the Creative Commons Attribution International License (CC BY). http://creativecommons.org/licenses/by/4.0/

\section{(c) (i) Open Access}

\begin{abstract}
Over half of the solar energy consists of near-infrared, and in addition to natural near-infrared, humans are increasingly exposed to artificial near-infrared from electrical appliances. Thus, we are exposed to tremendous amounts of near-infrared. Despite the wide prevalence of a variety of ultraviolet blocking materials, the necessity to protect against near-infrared has not been well recognized. To clarify the necessity to protect against near-infrared, we assessed cell viability of human fibroblast cells after water-filtered broad-spectrum near-infrared (1100 - $1800 \mathrm{~nm}$ together with a water-filter that excludes wavelengths $1400-1500 \mathrm{~nm}$ ) treatment using 2 sets of transparent polycarbonate plates, one to block ultraviolet and the other to block both ultraviolet and near-infrared. The cell viability was significantly decreased after 10 rounds of near-infrared irradiation at $20 \mathrm{~V} \mathrm{~cm}^{2}$ in near-infrared treated cells without a protective polycarbonate plate and near-infrared treated cells using the polycarbonate plate to block only ultraviolet. Assuming that the cell viability of the non-irradiated control to be 100 , the cell viability of the near-infrared treated cells without any protection was 0.2 . The cell viability of the near-infrared treated cells with the polycarbonate plate to block only ultraviolet was 0.3 , whereas both ultraviolet and nearinfrared protected cells retained a viability of 85.1. The results of this study indicate that protection from not only ultraviolet but also near-infrared should be considered to prevent skin damage.
\end{abstract}

\section{Keywords}

Near-Infrared, Protection, Skin Damage, Ultraviolet

\section{Introduction}

Despite the wide prevalence of a variety of UV blocking materials, such as sunblock, eyewear, films, umbrellas, and fibers, that are useful in protecting skin against UV exposure, NIR cannot be blocked and the necessity to

\footnotetext{
${ }^{*}$ Protection from Near-infrared.
} 
protect against near-infrared has not been well recognized. NIR can penetrate the skin and the sclera and affect the deeper tissues, including muscles, lens, and retina, with its high permeability. Thus, NIR can induce various biological effects [1]-[19]. Continual long-term exposure to NIR performs as an aging factor. Consequently, NIR can induce various kinds of tissue damage and diseases, such as undesirable photoaging [17] [18], long-lasting vasodilation [8], long-lasting muscle thinning [4], sagging and skin ptosis [17] [18], and potentially photocarcinogenesis, when biological NIR protection is not achieved [17] [18].

As human skin is exposed to tremendous amounts of both solar and artificial NIR from medical devices and electrical appliances [20] [21], and most UV blocking materials cannot block NIR, blocking materials should be equipped with protection ability against NIR also [10] [17] [18].

To clarify the necessity to protect against NIR, we assessed cell viability of human fibroblast cells after NIR treatment using 2 sets of transparent polycarbonate plates, one to block UV and the other to block both UV and NIR.

\section{Materials and Methods}

\subsection{NIR Device}

NIR irradiation was performed with a broadband NIR source (Titan; Cutera, Brisbane, CA, USA). The NIR device emits an NIR spectrum between 1100 and $1800 \mathrm{~nm}$, with water filtering to remove wavelengths between 1400 and $1500 \mathrm{~nm}$, and simulates solar NIR radiation that reaches the skin of humans on the Earth’s surface. To avoid thermal effects, the sapphire contact cooling tip was set to a fixed temperature of $20^{\circ} \mathrm{C}$. These specific wavelengths and the cooling system enabled the delivery of NIR to the cells located at the bottom of the 96-well microtiter plates.

\subsection{NIR Treatment}

In our previous in vitro study, ten rounds at $20 \mathrm{~J} / \mathrm{cm}^{2}$ achieved drastic reduction in cell count. Therefore, we performed 10 rounds of NIR irradiation at $20 \mathrm{~J} / \mathrm{cm}^{2}$. Well temperatures were monitored during exposure sessions and sequential pulses were only delivered after well temperature returned to $37^{\circ} \mathrm{C}$. This was monitored to prevent accumulated heating from multiple exposures from impacting the data. The temperatures of cultured media in the wells were monitored at 4-mm depth using a digital thermometer MC3000-000 with a sheathed thermocouple (IHKN053; $0.3 \mathrm{~mm}$ outer diameter of sheathed temperature sensor) purchased from Chino (Tokyo, Japan).

\subsection{Polycarbonate Plate}

A polycarbonate plate to block UV (Panlite L-1225Z 100, TEIJIN LIMITED, Tokyo, Japan) and a polycarbonate plate to block both UV and NIR (Panlite AM-1107ZV; TEIJIN LIMITED, Tokyo, Japan) were used in this study (see Figure 1). The thickness of each plate is $2 \mathrm{~mm}$. The transmission spectra of the polycarbonate plates are shown in Figure 2.

\subsection{Cell Culture}

Testing was conducted on cultures of human fibroblast cells. The cells were seeded in 96-well microtiter plates at a concentration of $1.0 \times 10^{4}$ cells per well in $100 \mu \mathrm{L}$ of medium. All cells were grown at $37^{\circ} \mathrm{C}$ in a humidified incubator with $5 \% \mathrm{CO}_{2}$.

\subsection{Cell Proliferation Assay}

3-(4,5-dimethythiazol-2-yl)-2,5-diphenyl tetrazolium bromide (MTT) assay was used to investigate cell viability of cultured cells after NIR treatment. The cells were cultured for $24 \mathrm{~h}$ before receiving NIR treatment. After $24 \mathrm{~h}$ incubation, the growth medium was removed and $100 \mu \mathrm{l}$ of $0.05 \%$ MTT solution (Wako pure Chemical Industries, Tokyo, Japan) was added to the culture. The cells were incubated for an additional $4 \mathrm{~h}$ at $37^{\circ} \mathrm{C}$ and then lysed with $100 \mu \mathrm{l}$ of lysis buffer [20\% sodium dodecyl sulfate (SDS) and 50\% N,N-dimethyl formamide (DMF), $\mathrm{pH}$ 4.7]. 


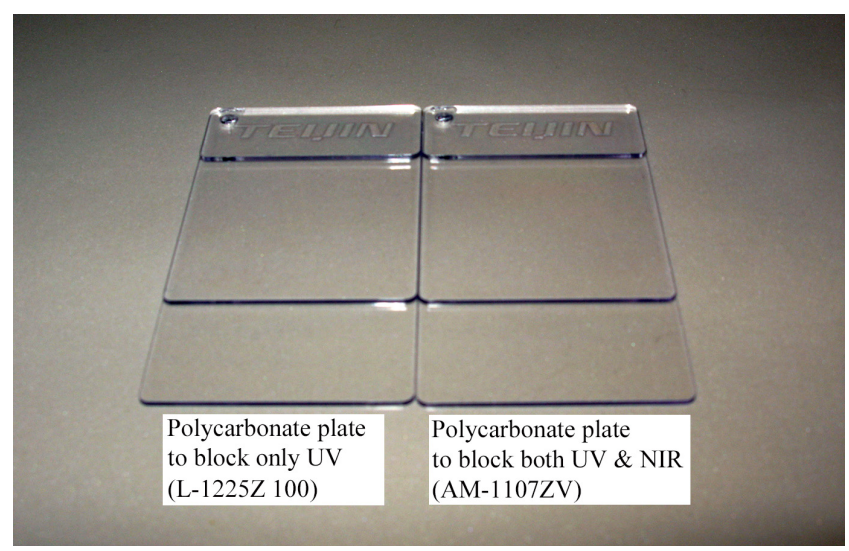

Figure 1. The appearance of the polycarbonate plates to block UV (Left), to block UV and NIR (Right).

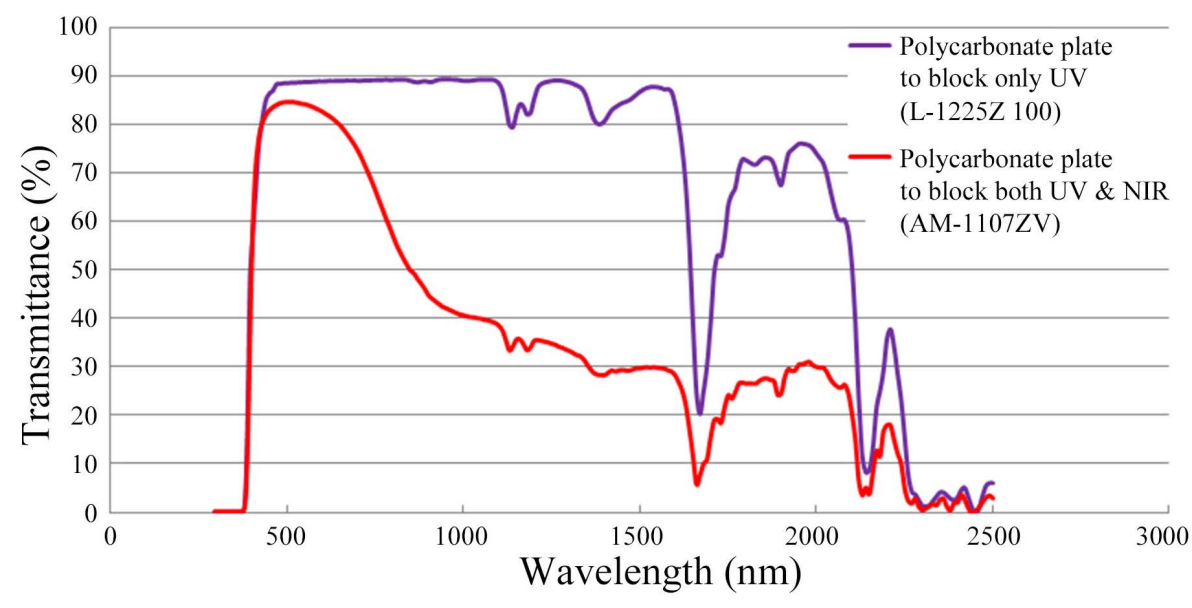

Figure 2. The transmission spectra of the polycarbonate plates, ranging from 295 to $2500 \mathrm{~nm}$.

\subsection{Statistical Analyses}

Statistical analysis was performed using the statistical package for social science (SPSS) software. $P<0.05$ was considered to indicate statistical significance.

\section{Results}

The cell viability was significantly decreased after 10 rounds of NIR irradiation at $20 \mathrm{~J} / \mathrm{cm}^{2}$ in NIR treated cells without a protective polycarbonate plate and NIR treated cells using the polycarbonate plate to block only UV. Assuming that the cell viability of the non-irradiated control to be 100, the cell viability of NIR treated cells without any protection was 0.2 . The cell viability of the NIR treated cells with the polycarbonate plate to block only UV was 0.3 , the cell viability of the NIR treated cells with the polycarbonate plate to block both UV and NIR was 85.1, as shown in Figure 3.

\section{Discussion}

Biological effects of sun and UV exposure have been extensively investigated. However, although over half of the solar energy is NIR, and in addition to natural NIR, humans are continuously exposed to artificial NIR from electrical appliances, the biological effects of NIR have not been well investigated. A water-filter is indispensable to experimentally simulate the solar NIR that reaches the skin [12] [17], as solar NIR is filtered by atmospheric water [22] [23]. Contact cooling is also recommended for investigation of the properties of solar NIR, as NIR increases the surface temperature and induces thermal effects [12] [17]. 


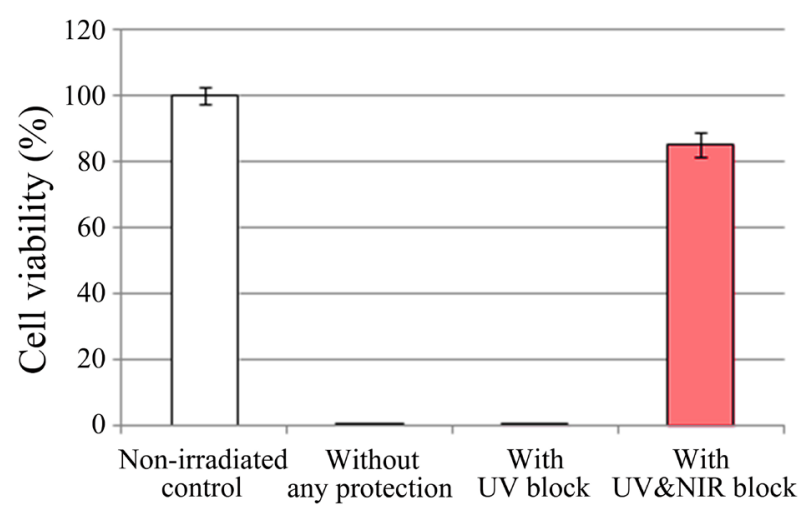

Figure 3. The cytotoxicity of NIR treatment of human fibroblast cells were evaluated by MTT assay.

Without a water filter or contact cooling, NIR immediately increases the temperature of the superficial layer of culture fluid in a laboratory dish or skin, as NIR is predominantly absorbed by hydrogen bond-containing molecules, such as water and hemoglobin. The energy of NIR then decreases as it penetrates deeper, and will not reach enough target cells in the base or deeper tissues. To accurately investigate the biological effects of solar NIR, a water-filter that excludes wavelengths between 1400 and $1500 \mathrm{~nm}$ and the cooling system are indispensable [12] [17].

NIR exhibits both wave and particle properties and appears to resonate hydrogen bonds and alpha helices, and therefore can affect the deeper tissues and induce various biological effects [10] [17]. The NIR spectrum is a result of the overtones and combination of bond stretching vibrations from $\mathrm{O}-\mathrm{H}, \mathrm{C}-\mathrm{H}$, and $\mathrm{N}-\mathrm{H}$ groups [24]. Humans have biological protective mechanisms against NIR that absorb NIR by induction of substances rich in hydrogen bonds and alpha helices, or reflect NIR by induction of fatty acid to protect the subcutaneous tissues against NIR [17]. NIR is absorbed by cotton or wool clothing rich in hydrogen bonds and alpha helices, water in perspiration and blisters, hemoglobin and water in vasodilation, keratin in hair and the stratum corneum, and water-binding proteins and water in the dermis, and is reflected by adipose tissue [17].

NIR performs as an aging factor, where biological NIR protection is not complete. NIR induces photoaging similar to that observed in solar elastosis, and enhances UV-induced dermal damage [25]. Long-term exposure of NIR from various heat sources, such as fires and stoves, results in erythema ab igne [26], and results in histopathological changes similar to those seen in solar-damaged skin [27]. The occurrence of telangiectasia appeared to increase with age, increased sunbathing, and poor pigmentation ability [28].

NIR induces various kinds of tissue damage and diseases, such as undesirable photoaging, long-lasting vasodilation, muscle thinning, skin ptosis, sagging, cataracts, and potentially photocarcinogenesis are induced by long-term NIR exposure. In addition, skin tumors appeared faster after irradiation with the full lamp spectrum containing UV, visible, and NIR compared to irradiation with UV alone [29].

Other than the biological materials for NIR block, various kinds of materials have been developed, such as metal oxides, compounds containing indium, and organic compounds in the industrial field. NIR is also emitted from monitors, screens, and electrical appliances, so materials for NIR block often require transparency [17].

In this study, compared to the non-irradiated control and the cells with protection from both UV and NIR, the cell viability in the cells without any protection and only protection from UV were significantly decreased. These results suggest that UV blocking is not sufficient and NIR blocking is essential to prevent skin damage.

It should be noted that this was a preliminary study based on experiments in only one human fibroblast cell line. Additional studies are warranted in larger numbers and various types of human cell types and with longer post-treatment periods to evaluate the variations in treatment parameters.

\section{Conclusion}

Water-filtered broad-spectrum NIR (1100 - $1800 \mathrm{~nm}$ combined with a water-filter that excludes wavelengths $1400-1500 \mathrm{~nm}$ ), which simulates solar NIR radiation that reaches the skin of humans on the Earth's surface, decreased the fibroblast cell viability. Thus, further protection from NIR should be widely prevalent to prevent photoaging and photocarcinogenesis, as standard UV blocking materials do not sufficiently block NIR. 


\section{Acknowledgements}

We thank the members of TEIJIN LIMITED for precise data and the file for Figure 2.

\section{References}

[1] Tanaka, Y., Matsuo, K., Yuzuriha, S. and Shinohara, H. (2009) Differential Long-Term Stimulation of Type I versus Type III Collagen after Infrared Irradiation. Dermatologic Surgery, 35, 1099-1104. http://dx.doi.org/10.1111/j.1524-4725.2009.01194.X

[2] Tanaka, Y., Matsuo, K. and Yuzuriha, S. (2009) Long-Term Evaluation of Collagen and Elastin Following Infrared (1100 to $1800 \mathrm{~nm}$ ) Irradiation. Journal of Drugs in Dermatology, 8, 708-712.

[3] Tanaka, Y., Matsuo, K., Yuzuriha, S., Yan, H. and Nakayama, J. (2010) Non-Thermal Cytocidal Effect of Infrared Irradiation on Cultured Cancer Cells Using Specialized Device. Cancer Science, 101, 1396-1402. http://onlinelibrary.wiley.com/doi/10.1111/j.1349-7006.2010.01548.x/epdf http://dx.doi.org/10.1111/j.1349-7006.2010.01548.x

[4] Tanaka, Y., Matsuo, K. and Yuzuriha, S. (2010) Long-Lasting Muscle Thinning Induced by Infrared Irradiation Specialized with Wavelength and Contact Cooling: A Preliminary Report. ePlasty, 10, e40.

http://www.eplasty.com/index.php?option=com_content\&view=article\&id=453\&catid=171:volume-10-eplasty-2010

[5] Tanaka, Y., Matsuo, K. and Yuzuriha, S. (2010) Long-Term Histological Comparison between Near-Infrared Irradiated Skin and Scar Tissues. Clinical, Cosmetic and Investigational Dermatology, 3, 143-149.

http://www.dovepress.com/articles.php?article_id=5752 http://dx.doi.org/10.2147/CCID.S15729

[6] Tanaka, Y., Matsuo, K. and Yuzuriha, S. (2011) Long-Lasting Relaxation of Corrugator Supercilii Muscle Contraction Induced by Near Infrared Irradiation. ePlasty, 11, e6.

http://www.eplasty.com/index.php?option=com_content\&view=article\&id=519\&catid=172:volume-11-eplasty-2011

[7] Tanaka, Y., Matsuo, K. and Yuzuriha, S. (2011) Near-Infrared Irradiation Non-Thermally Affects Subcutaneous Adipocytes and Bones. ePlasty, 11, e12.

http://www.eplasty.com/index.php?option=com_content\&view=article\&id=528\&catid=172:volume-11-eplasty-2011

[8] Tanaka, Y., Matsuo, K. and Yuzuriha, S. (2011) Near-Infrared Irradiation Non-Thermally Induces Long-Lasting Vasodilation by Causing Apoptosis of Vascular Smooth Muscle Cells. ePlasty, 11, e22.

http://www.eplasty.com/index.php?option=com_content\&view=article\&id=541\&catid=172:volume-11-eplasty-2011

[9] Tanaka, Y., Matsuo, K. and Yuzuriha, S. (2011) Objective Assessment of Skin Rejuvenation Using Near-Infrared 1064-nm Neodymium: YAG Laser in Asians. Clinical, Cosmetic and Investigational Dermatology, 4, 123-130. http://dx.doi.org/10.2147/CCID.S22841

[10] Tanaka, Y. and Matsuo, K. (2011) Non-Thermal Effects of Near-Infrared Irradiation on Melanoma. In: Tanaka, Y., Ed., Breakthroughs in Melanoma Research, InTech, Croatia, 597-628.

http://www.intechopen.com/books/breakthroughs-in-melanoma-research/non-thermal-effects-of-near-infrared-irradiati on-on-melanoma http://dx.doi.org/10.5772/38663

[11] Tanaka, Y., Tatewaki, N., Nishida, H., Eitsuka, T., Ikekawa, N. and Nakayama, J. (2012) Non-Thermal DNA Damage of Cancer Cells Using Near-Infrared Irradiation. Cancer Science, 103, 1467-1473.

http://onlinelibrary.wiley.com/doi/10.1111/j.1349-7006.2012.02310.x/epdf http://dx.doi.org/10.1111/j.1349-7006.2012.02310.x

[12] Tanaka, Y. (2012) Impact of Near-Infrared in Dermatology. World Journal of Dermatology, 1, 30-37. http://dx.doi.org/10.5314/wjd.v1.i3.30

[13] Tanaka, Y. and Kawashima, M. (2012) The Biological Effects of Near-Infrared. Aesthetic Dermatology, 22, $100-109$. (In Japanese)

[14] Tanaka, Y., Tunemi, Y., Kawashima, M. and Nishida, H. (2013) The Impact of Near-Infrared in Plastic Surgery. Plastic Surgery: An International Journal, Article ID: 973073.

http://www.ibimapublishing.com/journals/PSIJ/2013/973073/973073.pdf http://dx.doi.org/10.5171/2013.973073

[15] Tanaka, Y. and Gale, L. (2013) The Effect of Near-Infrared between 1100-1800 nm Together with a Water-Filter and a Contact Cooling. Anaplastology, 2, 3.

[16] Tanaka, Y., Tunemi, Y., Kawashima, M., Tatewaki, N. and Nishida, H. (2013) Objective Assessment of Skin Tightening Using a Water-Filtered Near-Infrared (1000-1800 nm) Device with a Contact Cooling and Freezer Stored Gel. Clinical, Cosmetic and Investigational Dermatology, 6, 167-176. http://dx.doi.org/10.2147/CCID.S47299 
[17] Tanaka, Y. and Gale, L. (2013) Beneficial Applications and Deleterious Effects of Near-Infrared from Biological and Medical Perspectives. Optics and Photonics Journal, 3, 31-39. http://dx.doi.org/10.4236/opj.2013.34A006

[18] Tanaka, Y. and Gale, L. (2013) The Necessity of Near-Infrared Protection. Surgery: Current Research, 3, 150.

[19] Tanaka, Y., Tatewaki, N., Fujimoto, T. and Nishida, H. (2014) Non-Thermal Anticancer Effects of Water-Filtered Broad-Spectrum Near-Infrared Irradiation. International Journal of Cancer Research, 48, 1258-1265.

[20] Schieke, S.M., Schroeder, P. and Krutmann, J. (2003) Cutaneous Effects of Infrared Radiation: From Clinical Observations to Molecular Response Mechanisms. Photodermatology, Photoimmunology \& Photomedicine, 19, $228-234$. http://onlinelibrary.wiley.com/doi/10.1034/j.1600-0781.2003.00054.x/epdf http://dx.doi.org/10.1034/j.1600-0781.2003.00054.x

[21] Schroeder, P., Lademann, J., Darvin, M.E., Stege, H., Marks, C., Bruhnke, S. and Krutmann, J. (2008) Infrared RadiationInduced Matrix Metalloproteinase in Human Skin: Implications for Protection. Journal of Investigative Dermatology, 128, 2491-2497. http://www.nature.com/jid/journal/v128/n10/pdf/jid2008116a.pdf http://dx.doi.org/10.1038/jid.2008.116

[22] Anderson, R.R. and Parrish, J.A. (1981) The Optics of Human Skin. Journal of Investigative Dermatology, 77, 13-19. http://dx.doi.org/10.1111/1523-1747.ep12479191

[23] Gates, D.M. (1966) Spectral Distribution of Solar Radiation at the Earth’s Surface. Science, 151, 523-529. http://www.sciencemag.org/content/151/3710/523.extract http://dx.doi.org/10.1126/science.151.3710.523

[24] Weyer, L.G. (1985) Near-Infrared Spectroscopy of Organic Substances. Applied Spectroscopy Reviews, 21, 1-43. http://www.tandfonline.com/doi/abs/10.1080/05704928508060427\#.VQO8dpSCh0I http://dx.doi.org/10.1080/05704928508060427

[25] Kligman, L.H. (1982) Intensification of Ultraviolet-Induced Dermal Damage by Infrared Radiation. Archives of Dermatological Research, 272, 229-238. http://link.springer.com/article/10.1007/BF00509050\# http://dx.doi.org/10.1007/BF00509050

[26] Findlayson, G.R., Sams Jr., W.M. and Smith, J.G. (1966) Erythema AB Igne: A Histopathological Study. Journal of Investigative Dermatology, 46, 104-108.

[27] Page, E.H. and Shear, N.H. (1988) Temperature-Dependent Skin Disorders. Journal of the American Academy of Dermatology, 18, 1003-1019. http://dx.doi.org/10.1016/S0190-9622(88)70098-5

[28] Berg, M. (1989) Epidemiological Studies of Influence of Sunlight on the Skin. Photodermatology, 6, 80-84.

[29] Bain, J.A., Rusch, H.P. and Kline, B.E. (1943) The Effect of Temperature upon Ultraviolet Carcinogenesis with Wave Length 2,800-3,400 Å. Cancer Research, 3, 610-612. 